2. Запорожець Ю. М. Теплові електростанції України перед дилемою: або закриття або інтенсивне відновлення. / Ю.М. Запорожець // Наукові праці. Техногенна безпека, вип.198, том 210, 2013. С. 31-36.

3. Пристер Б.С.Проблемы безопасности атомний энергетики. Уроки Чернобыля./Б.С.Пристер, А.А.Ключников, В.М.Шестопалов, В.П.Кухарь //-Київ,- 2012p., ПАТ «ВІПОЛ»-201с.

4. Патон Б.Є. Перспективи розвитку вітчизняної парогазової технології./ Б.С.Патон, А.А.Долинський, А.А.Халатов і інш. // -Вісник НАН України (Київ), 2009. №4. С. 61-69.

DOI https://doi.org/10.30525/978-9934-26-047-6-24

\title{
ECOLOGICAL AND FORESTRY ESSENCE OF BACTERIOSI OF FOREST WOODY PLANTS IN THE FORESTS OF THE FOREST-STEPPE AND POLISSYA OF UKRAINE
}

\author{
Kulbanska I. M. \\ Ph.D. in Biological Science, \\ Associate Professor at the Department of Forestry \\ National University of Life and Environmental Sciences of Ukraine \\ Kyiv, Ukraine \\ Goychuk A. F. \\ Doctor of Agricultural Sciences, Professor, \\ Professor at the Department of Forestry \\ National University of Life and Environmental Sciences of Ukraine \\ Kyiv, Ukraine \\ Shvets M. V. \\ Ph.D. in Biological Science, \\ Department of Biology and Forest Protection \\ Polissia National University \\ Zhytomyr, Ukraine
}

The conducted experimental research in conjunction with the critical analysis of literature points to the need to expand the work on the clarification of bacterial pathology of the mentioned, and other forest tree plants. Studies of recent years, including and in Ukraine, experimentally 
confirmed the presence in healthy trees in the minor quantities of fungi and bacteria (as endophytes), the ecological niche of which are living cells. In a healthy plant, pathogenic endophytes, in particular bacteria, are in a depressed state. Their number is on orders of magnitude less than endophytic saprotrophs and is always less than the threshold concentration required to start the infectious process. This is not due to the lack of nutrients, but due to other factors, in particular the antagonistic activity of endophytic micromycetes and spore bacteria in them in the systemic interaction of the components of the endophytic automico- and microbiota of the plant. Pathogenic endophytes (the so-called vital obligates) are selected by the plant and perform a wide range of biocontrol, regulatory and protective functions through direct antagonism to pathogens or the induction of the resistance system by limiting its activity. Some endophytes prevent the introduction pathogenic species in plants, protect it from nematodes and harmful insects. In a healthy plant, pathogenic endophytes are usually in a depressed state. Their number is on an order of magnitude lower than endophytic saprotroph, and always less than the threshold concentration necessary to start the infectious process. In case of violation of systemic interactions in the plant and, in the first instance, in violation of metabolic processes under the influence of various, often not fully elucidated factors, including and abiotic, pathogenic endophytic myco- and microorganisms can cause infectious pathology of plants without the participation of external infectious agents. Therefore, it is extremely important to study the ways and methods of induction of demutation processes in forest biocenosis as regulatory factors of automico- and microbiota.

Currently, bacteriosis and their pathogens are largely studied for plants of agrocenosis. As for the bacteriosis of forest trees, they have not been studied sufficiently, although in recent decades increased attention has been paid to this problem [1, 2, 3, 4]. It is emphasized that on forest trees in the world several dozens of bacteriosis with different degrees of damage caused by bacteria of genera Pseudomonas, Xanthomonas, Enterobacter, Erwinia, Agrobacterium, Brenneria, Xylella, Rhizobium, Corynebacterium, Bacillus, Clostridium etc. are described [4]. Bacteriosis equally affects forest trees in natural forest stands, forest crops, field bands, urban, park and forest park stands, and so on. Currently, those or other bacteriosis are known in almost all forest trees.

In conditions of increasing the impact of adverse as abiotic, in particular, synoptic, and biotic, including and parasitic, factors on forest biocenosis is extremely important timely assessment (diagnosis, monitoring) of the state of forests. It is these aspects that are devoted to our research. 
The general scheme of research on bacterial diseases of forest trees, in particular, Pinus sylvestris, Quercus robur, Fraxinus excelsior, Betula pendula, etc., included the following stages: reconnaissance and detailed forest-pathological surveys according to generally accepted forestry and phytopathological methods; selection of affected organs and tissues; isolation of myco- and microorganisms in pure culture; testing of pathogenic properties of isolated samples and their identification; research of antagonistic relations in the system "bacteria-bacteria", "bacteria-fungus" as possible factors of induction of demutation processes in forest biocenosis. In addition, the influence of meteorological (synoptic) factors as pathological catalysts and the harmful entomofauna in the context of the trophic connections between insects and phytopathogenic microorganisms and as a vector in the spread of bacteriosis were investigated.

The massive death of forests, both in the world and in Ukraine, has been known since the 19th century. Currently, epiphytotic dying of coniferous trees within their range, in particular pine, which causes significant environmental and economic losses, is a matter of serious concern.

The first of disease focus in pine forests were recorded in Ukraine in 2011 in the Zhytomyr region, and by 2015 the "biological fire" has spread in the northwest direction. In 2017, pine death was detected in the central regions of Ukraine, and by spring survey in 2018 disease in the forest-steppe were also installed [4]. On the Scots pine were detected bacterial diseases such as cancerous-ulcer disease, bacterial burn, bacterial dropsy, bacterial ulcers, bacterial root cancers, tumorous bacteriosis, black bacteriosis and vascular bacteriosis of seedlings [1].

From organs of externally healthy Scots pine, including seeds, we isolated real FB-endophytes ( $P$. syringae, $P$. carotovorum, E. nimipressuralis), which caused Pinus sylvestis disease in an artificial infection, and conditional phytopathogenic (P. fluorescens, $P$ polymyxa, P. agglomerans) and saprotrophic (Bacillus subtilis, B. pumilus) bacteria, as well as various systematic and functional groups of mycosomes, including anamorphs of the genus Ceratocystis sp. (known as pathogens sinensis) as components of the deep pathology of this valuable forest tree plant [4].

The catalytic factor in the epiphytotic dying of forest trees, in particular pine trees in Ukraine, is the so-called hydrothermal stress (there are reasons to believe that in other countries as well).

Due to the extraordinary intensity of the pathological process, we have reason to assert that the epiphytotic death of the pine, causing the two most harmful bacteriosis on the pine - bacterial burns (usually spreading to the upper part of the crown and leading to its rapid dying) and bacterial dropsy 
(in the lower part of the trunk) associated with the activation of FBendophytes under the influence of adverse synoptic (as catalysts) factors.

In recent decades there has been epiphytotic dieback of the birch associated with vascular parenchymal bacteriosis, which has different names (bacterial dropsy, bacterial wet cancer, brown slime, watermark disease, "crying" of birch, "wetwood", "Slime flux", "alcoholic flux", etc., but a common etiology and pathogenesis. The causative agent of the bacterial dropsy of the birch in Ukraine is the polybiotroph Enterobacter nimipressuralis, the pathogenicity of which is proved in the experiment both during spring and autumn inoculation of experimental plants [2].

In the pathology of bacterial dropsy, in addition to E. nimipressuralis, have been identified Xanthomonas campestris, Pantoea agglomerans associated with disease (showed variable pathogenic properties indicating a possible extension of the range of nutritional plants for the mentioned bacteria), Bacillus subtilis and micromycetes from the Zygomycota, Ascomicota, Deuteromycota divisions [2].

The mass death of Fraxinus excelsior was first registered in the early 1990's in northeastern Poland and Lithuania (according to recent data, more than 30 thousand hectares, or $60 \%$ of the total area of the forest stands, are now affected of disease). Currently, in European countries, mass death of ash is associated with the anamorphic fungus Chalara fraxinea, an anamorphous Hymenosyphus pseudoalbidus [5], causing the pathology of the so-called «ash dieback». We have isolated several species of anamorphic fungi and bacteria from such lesions in the conditions of Podillya of Ukraine, in particular Pseudomonas syringae pv. savastanoi, Erwinia horticola and Xanthomonas sp. Artificial infection of ash with micromycetes did not lead to symptoms like "ash dieback", and infection with bacteria caused pathological processes, similar to tuberculosis $F$. excelsior [3].

From the lesions of tuberculosis, we have identified 7 types of bacteria P. syringae pv. savastanoi, P. fluorescens, P. syringae, Pseudomonas sp., E. herbicola, E. horticola, Xanthomonas sp. Also, in samples of diseased tissues revealed sporonic bacteria, mainly the genus Bacillus, which in further studies revealed some antagonistic properties to $P$. syringae pv. savastanoi and associated and conditionally pathogenic bacteria associated with it in the F. excelsior tuberculosis pathology [3].

In recent years there have been reports of single deaths of oak. In the last century in Ukraine there were three waves of mass destruction, the most powerful in the 70's. At present, the following bacterial diseases are found in oak: soft rot of acorns, bacterial dropsy, droplet disease of acorns, dry rot of branches and trunks, cancer-ulcer disease and associated other systematic 
and functional groups of mycosis and microorganisms. There is currently a certain activation of the bacterial dropsy. The analysis of model trees indicates the systemic nature of the disease, the causative agent of which affects the plumbing system of trunks and branches of various orders, and externally manifested by the release of a dark, almost black exudate. According to the literature and our research, the causative agent of bacterial edema of wood species is a bacterium Lelliottia nimipressuralis (Carter 1945) Brady et al. 2013.

The need to deepen studies of pathogenic components of automicrobiota, in particular in the context of understanding both the general biological problems of pathology and the goal of developing forest protection measures, is noted.

\section{References:}

1. Cherpakov, V.V. Bacterial diseases of forest species in pathology of forest. SPb. : SPb GLTU, 2012, 292-303 (in Russian).

2. Goychuk A. F., Drozda V. F., Shvets M.V., Kulbanska I.M. Bacterial wetwood of silver birch (Betula pendula Roth): symptomology, etiology and pathogenesis. Folia Forestalia Polonica, Series A - Forestry, 2020. Vol. 62 (3), 145-159.

3. Goychuk A., Kulbanska I., Shvets M. Bacteria associated with Pseudomonas syringae pv. savastanoi in the pathology of Fraxinus excelsior L. Mikrobiol. Z. 2020; 82 (3): 22-34.

4. Gvozdyak, R.I., Goychuk, A.F., Rozenfeld, V.V. \& Pasichnik, L.A., Bacterial diseases of pine (Pinus sylvestris L.) and its floral microflora: Monograph. Zhitomir : Polissya. 2011, 224 (in Ukrainian).

5. Kowalski, T., \& Holdenrieder, O. Chalara fraxinea causes dieback of ash (Fraxinus excelsior) in Europe report. For. Pathol., 2009. № 39. C. 1-7. 